This Section of Epidemiology and Psychiatric Sciences appears in each issue of the Journal to stress the relevance of epidemiology for behavioral neurosciences, reporting the results of studies that explore the use of an epidemiological approach to provide a better understanding of the neural basis of major psychiatric disorders and, in turn, the utilisation of the behavioural neurosciences for promoting innovative epidemiological research.

The ultimate aim is to help the translation of most relevant research findings into every-day clinical practice. These contributions are written in house by the journal's editorial team or commissioned by the Section Editor (no more than 1000 words, short unstructured abstract, 4 key-words, one Table or Figure and up to ten references).

Paolo Brambilla, Section Editor

\title{
Pharmacological properties of cannabidiol in the treatment of psychiatric disorders: a critical overview
}

\author{
G. M. Mandolini ${ }^{1}$, M. Lazzaretti ${ }^{1}$, A. Pigoni ${ }^{1}$, L. Oldani ${ }^{1}$, G. Delvecchio ${ }^{2}$ and P. Brambilla ${ }^{2,3 *}$ \\ ${ }^{1}$ Department of Neurosciences and Mental Health, Fondazione IRCCS Ca' Granda Ospedale Maggiore Policlinico, University of Milan, Milan, Italy \\ ${ }^{2}$ Department of Pathophysiology and Transplantation, University of Milan, Milan, Italy \\ ${ }^{3}$ Scientific Institute IRCCS 'E. Medea', Bosisio Parini (Lc), Italy
}

\begin{abstract}
Cannabidiol (CBD) represents a new promising drug due to a wide spectrum of pharmacological actions. In order to relate CBD clinical efficacy to its pharmacological mechanisms of action, we performed a bibliographic search on PUBMED about all clinical studies investigating the use of $\mathrm{CBD}$ as a treatment of psychiatric symptoms. Findings to date suggest that (a) CBD may exert antipsychotic effects in schizophrenia mainly through facilitation of endocannabinoid signalling and cannabinoid receptor type 1 antagonism; (b) CBD administration may exhibit acute anxiolytic effects in patients with generalised social anxiety disorder through modification of cerebral blood flow in specific brain sites and serotonin 1A receptor agonism; (c) CBD may reduce withdrawal symptoms and cannabis/tobacco dependence through modulation of endocannabinoid, serotoninergic and glutamatergic systems; (d) the preclinical pro-cognitive effects of CBD still lack significant results in psychiatric disorders. In conclusion, current evidences suggest that CBD has the ability to reduce psychotic, anxiety and withdrawal symptoms by means of several hypothesised pharmacological properties. However, further studies should include larger randomised controlled samples and investigate the impact of CBD on biological measures in order to correlate CBD's clinical effects to potential modifications of neurotransmitters signalling and structural and functional cerebral changes.
\end{abstract}

Received 2 March 2018; Accepted 28 April 2018

Key words: Antianxiety agents, antipsychotics, clinical drug studies, drugs new, psychopharmacology.

Cannabidiol (CBD) represents the second most abundant phytocannabinoid in Cannabis plant after the psychoactive tetrahydrocannabinol $(\triangle 9-\mathrm{THC})$ and, in recent years, an increasing body of evidences emphasised its promising role as a treatment in several

\footnotetext{
* Address for correspondence: Paolo Brambilla, Department of Neurosciences and Mental Health, Fondazione IRCCS $\mathrm{Ca}^{\prime}$ Granda Ospedale Maggiore Policlinico, via F. Sforza 35, 20122 Milan, Italy.

(Email: paolo.brambilla1@unimi.it)
}

medical conditions (Fasinu et al. 2016). Indeed, CBD exhibits various therapeutic effects that range from antioxidant, anti-inflammatory and neuroprotective (Watt \& Karl, 2017) to anticonvulsive (Perucca, 2017), anti-emetic (Parker et al. 2011) and analgesic (Lötsch et al. 2018).

Moreover, several animal studies and clinical trials on healthy controls suggested its potential role as an antipsychotic (Hahn, 2018), anxiolytic (Soares \& Campos, 2017) and anti-craving (Lee et al. 2017) 
drug, as well as a pro-cognitive (Osborne et al. 2017) and antidepressant (de Mello Schier et al. 2014) compound. Therefore, it is not surprising that CBD has been considered as a new potential treatment in several psychiatric disorders.

In this regard, in order to link the so far hypothesised pharmacological mechanisms of action of CBD to its clinical effect in psychiatric disorders, we performed a bibliographic search in PubMed using 'Cannabidiol AND Psychiatry', 'Cannabidiol AND Psychosis', 'Cannabidiol AND Schizophrenia', 'Cannabidiol AND Bipolar Disorder', 'Cannabidiol AND Depression', 'Cannabidiol AND Anxiety', 'Cannabidiol AND Substance Use Disorder', 'Cannabidiol AND Withdrawal Syndrome' as key words. Additional articles were identified through the reference lists of the papers. We selected published studies from January 1995 until April 2018. We excluded both pre-clinical studies and clinical trials in healthy controls. Fourteen studies were finally included (five case reports, one open-label pilot study, one double-blinded controlled clinical trial, seven randomised double-blinded controlled clinical trials), matching methods and results summarised in Table 1.

\section{CBD and psychosis}

Eight studies evaluated the clinical effect of CBD in psychosis. Five of these studies found a beneficial effect of CBD in reducing psychotic symptoms in schizophrenia (SKZ) (Zuardi et al. 1995; Leweke et al. 2012; Leweke, 2013; McGuire et al. 2018) and in Parkinson's disease (Zuardi et al. 2009), while the others found only mild effects or no improvement over psychotic symptoms in patients with SKZ (Zuardi et al. 2006; Boggs et al. 2018) or in bipolar disorder (BD) patients experiencing a manic episode with psychotic features (Zuardi et al. 2010).

The majority of studies attributed the potential antipsychotic properties of CBD to its ability to directly inhibit the reuptake of anandamide, an endocannabinoid that exhibits neurogenic and anti-inflammatory activity (Pisanti et al. 2017) and plays a major role in mood regulation, cognition and behaviour (Di Marzo \& Petrosino, 2007). Moreover, CBD can also reduce endocannabinoids degradation by blocking fatty acid amide hydrolase function (Pisanti et al. 2017). Consequently, the increase of endocannabinoids, such as anandamide, in postsynaptic neurons may regulate presynaptic release of $\gamma$-aminobutyric acid and glutamate as well as stabilise dopamine neurotransmission (Gururajan \& Malone, 2016). Moreover, CBD has low affinity for cannabinoid receptor type 1 (CB1R) and type 2 (CB2R) with a not specific indirect antagonism when these receptors are activated by $\triangle 9$-THC (Pisanti et al. 2017). Therefore, CBD may likely contrast $\triangle 9$-THC psychotropic activity through a non-competitive negative allosteric modulation of CB1R by binding to a distinct allosteric site (Laprairie et al. 2015). Furthermore, while the antipsychotic effect of CBD has been mainly related to the enhanced endocannabinoids signalling, some authors recently hypothesised that CBD may exert its antipsychotic action through a partial agonist activity on dopamine D2 receptors, similarly to the atypical antipsychotic aripiprazole (Seeman, 2016), and through the activation of vanilloid receptor 1, a non-selective calcium channel, thus facilitating glutamate pre-synaptic release (Campos et al. 2012).

Interestingly, in the study carried out by Leweke et al. (Leweke et al. 2012), patients with SKZ were randomised to either amisulpride treatment or CBD administration for 28 days. The authors showed that both CBD and amisulpride groups had a significant reduction of psychotic symptoms and no difference in clinical efficacy was detected between the two different treatments. Moreover, the CBD group showed significantly higher serum level of both anandamide and fatty acid amide hydrolase substrates, a result which has been directly related to the CBD antipsychotic properties (Hahn, 2018). Finally, McGuire et al. (McGuire et al. 2018) detected a significant reduction of positive symptoms in patients with SKZ treated with CBD compared with placebo but the authors did not find any significant correlation between CBD plasma levels or its hydroxyl metabolites (6-OH-CBD, 7-OH-CBD) and the scores of scales assessing psychotic symptoms.

In conclusion, overall these evidences suggest that CBD may exert antipsychotic effects in patients with SKZ (Zuardi et al. 1995; Leweke et al. 2012; Leweke, 2013; McGuire et al. 2018) and Parkinson's psychosis (Zuardi et al. 2009). However, in three studies, CBD was ineffective to treat psychotic symptoms in BD patients (Zuardi et al. 2010) and outpatients with SKZ (Zuardi et al. 2006; Boggs et al. 2018). Moreover, the antipsychotic effect of CBD seemed to be related to the endocannabinoids plasma-level increase (Leweke et al. 2012), but not to CBD serum levels (McGuire et al. 2018). However, these results need further investigations. Therefore, since the facilitation of endocannabinoid signalling was the most likely hypothesised antipsychotic mechanism, the discrepancy of results among studies emphasised the need to evaluate endocannabinoid plasma-level changes in order to detect their potential contribution to the antipsychotic action.

\section{CBD and anxiety disorder}

The anxiolytic properties of CBD have been investigated by two clinical studies, carried out by the same 
Table 1. Summary of the studies described in the manuscript

\begin{tabular}{|c|c|c|c|c|c|c|c|c|c|}
\hline Article & Study design & Diagnosis & Sample (M/F) & $\begin{array}{c}\text { Age } \\
\text { (years old) }\end{array}$ & $\begin{array}{l}\text { CBD dosage/ } \\
\text { formulation }\end{array}$ & CBD timing & Augmentation & $\begin{array}{l}\text { Scales, test } \\
\text { and } \\
\text { measurements }\end{array}$ & Main results \\
\hline $\begin{array}{l}\text { Zuardi et al. } \\
\text { (1995) }\end{array}$ & Case report & $\begin{array}{l}\text { Treatment-resistant } \\
\quad \text { SKZ }\end{array}$ & $1(0 / 1)$ & 19 & $\begin{array}{l}1500 \mathrm{mg} / \text { day } \\
\text { of gelatin } \\
\text { capsules } \\
\text { (with } \\
\text { powder } \\
\text { CBD } \\
\text { dissolved in } \\
\text { corn oil) }\end{array}$ & 4 weeks & $\begin{array}{l}\text { Diazepam } \\
\text { co-medication } \\
\text { allowed }\end{array}$ & $\begin{array}{l}\text { BPRS } \\
\text { IOSPI } \\
\text { UKU }\end{array}$ & $\begin{array}{l}\text { Significant reduction of all } \\
\text { items of BPRS score } \\
\text { No side effects }\end{array}$ \\
\hline $\begin{array}{l}\text { Zuardi et al. } \\
\text { (2006) }\end{array}$ & Case report & $\begin{array}{l}\text { Treatment-resistant } \\
\quad \text { SKZ }\end{array}$ & $3(3 / 0)$ & $\begin{array}{l}23 \\
23 \\
22\end{array}$ & $\begin{array}{l}\text { CBD in two } \\
\text { daily doses, } \\
\text { from } 40 \mathrm{mg} / \\
\text { day until } \\
1280 \mathrm{mg} / \\
\text { day }\end{array}$ & 29 days & I & $\begin{array}{l}\text { BPRS } \\
\text { PANSS-N } \\
\text { CGI } \\
\text { UKU } \\
\text { SAS } \\
\text { BARS }\end{array}$ & $\begin{array}{l}\text { Mild or no symptoms } \\
\text { improvements } \\
\text { No side effects }\end{array}$ \\
\hline $\begin{array}{l}\text { Zuardi et al. } \\
\text { (2009) }\end{array}$ & $\begin{array}{l}\text { Open-label pilot } \\
\text { study }\end{array}$ & $\begin{array}{l}\text { Parkinson disease } \\
\text { with psychotic } \\
\text { symptoms }\end{array}$ & $6(4 / 2)$ & $58.8 \pm 14.9$ & $\begin{array}{l}150 \mathrm{mg} / \text { day } \\
\text { up to } 400 \\
\text { mg/day of } \\
\text { gelatin } \\
\text { capsules } \\
\text { (with } \\
\text { powder } \\
\text { CBD } \\
\text { dissolved in } \\
\text { corn oil) }\end{array}$ & 4 weeks & $\begin{array}{l}\text { Median of } 1050 \\
\text { mg/day of } \\
\text { L-dopa }\end{array}$ & $\begin{array}{l}\text { BPRS } \\
\text { PPQ } \\
\text { UPDRS } \\
\text { CGI } \\
\text { MMSE } \\
\text { FAB }\end{array}$ & $\begin{array}{l}\text { Significant reduction } \\
\text { psychotic symptoms. } \\
\text { No side effects }\end{array}$ \\
\hline $\begin{array}{l}\text { Hallak et al. } \\
\qquad(2010)\end{array}$ & $\begin{array}{l}\text { Double-blinded, } \\
\text { placebo-controlled } \\
\text { study }\end{array}$ & SKZ & $28(18 / 10)$ & $\begin{array}{l}\text { More than } \\
18\end{array}$ & $\begin{array}{l}300 \mathrm{mg} \text { CBD, } \\
600 \mathrm{mg} \\
\text { CBD or } \\
\text { placebo in } \\
\text { gelatin } \\
\text { capsules }\end{array}$ & $\begin{array}{l}\text { One single } \\
\text { dose }\end{array}$ & I & $\begin{array}{l}\text { BPRS } \\
\text { PANSS } \\
\text { SCWT }\end{array}$ & $\begin{array}{l}\text { Single acute administration } \\
\text { of CBD did not improve } \\
\text { SCWT performances. } \\
\text { Possible sedative effect } \\
\text { with } 600 \mathrm{mg} \text { dose }\end{array}$ \\
\hline
\end{tabular}




\begin{tabular}{|c|c|c|c|c|c|c|c|c|c|}
\hline Article & Study design & Diagnosis & Sample (M/F) & $\begin{array}{c}\text { Age } \\
\text { (years old) }\end{array}$ & $\begin{array}{l}\text { CBD dosage/ } \\
\text { formulation }\end{array}$ & CBD timing & Augmentation & $\begin{array}{c}\text { Scales, test } \\
\text { and } \\
\text { measurements }\end{array}$ & Main results \\
\hline $\begin{array}{l}\text { Leweke } \text { et al. } \\
\text { (2012) }\end{array}$ & $\begin{array}{l}\text { Double-blinded, } \\
\text { randomised, } \\
\text { parallel-group, } \\
\text { controlled clinical } \\
\text { trial of CBD } v . \\
\text { amisulpride }\end{array}$ & $\begin{array}{l}\text { SKZ or } \\
\text { schizophreniform } \\
\text { psychosis }\end{array}$ & $\begin{array}{l}20(15 / 5) \text { CBD } \\
\text { group }+19 \\
(17 / 2) \\
\text { amisulpride } \\
\text { group }\end{array}$ & $18-50$ & $\begin{array}{l}200 \mathrm{mg} / \text { day } \\
\text { up to } 800 \\
\mathrm{mg} / \text { day } \\
\text { CBD or } \\
\text { amisulpride }\end{array}$ & 4 weeks & $\begin{array}{l}\text { Lorazepam } \\
\text { co-medication } \\
\text { allowed }\end{array}$ & $\begin{array}{l}\text { BPRS } \\
\text { PANSS } \\
\text { EPS } \\
\text { CGI } \\
\text { SAS }\end{array}$ & $\begin{array}{l}\text { Significant clinical } \\
\text { improvement in both } \\
\text { groups. } \\
\text { Anandamide and FAAH } \\
\text { substrates levels higher } \\
\text { in CBD group. } \\
\text { Fewer side effects in the } \\
\text { CBD group }\end{array}$ \\
\hline $\begin{array}{l}\text { Leweke } \\
(2013)\end{array}$ & $\begin{array}{l}\text { Double-blind, } \\
\text { randomised, } \\
\text { placebo-controlled, } \\
\text { cross-over clinical } \\
\text { trial pf CBD } v \text {. }\end{array}$ & $\begin{array}{l}\text { First-episode } \\
\text { paranoid SKZ }\end{array}$ & 29 & NIA & $\begin{array}{l}600 \mathrm{mg} / \text { day } \\
\text { CBD }\end{array}$ & 14 days & NIA & NIA & $\begin{array}{l}\text { CBD improved psychotic } \\
\text { symptoms compared } \\
\text { with baseline }\end{array}$ \\
\hline $\begin{array}{l}\text { McGuire } \\
\text { et al. (2018) }\end{array}$ & $\begin{array}{l}\text { Double-blind, } \\
\text { randomised, } \\
\text { placebo-controlled, } \\
\text { parallel-group trial }\end{array}$ & $\begin{array}{l}\text { SKZ or a related } \\
\text { psychotic disorder }\end{array}$ & $\begin{array}{l}43 \text { (28/15) CBD } \\
\text { group }+45 \\
(23 / 22) \\
\text { placebo } \\
\text { group }\end{array}$ & $18-65$ & $\begin{array}{l}1000 \mathrm{mg} / \text { day } \\
\text { CBD (10 } \\
\mathrm{mL} \text { of a } 100 \\
\mathrm{mg} / \mathrm{mL} \text { oral } \\
\text { solution) or } \\
\text { placebo in } \\
\text { two doses }\end{array}$ & 6 weeks & $\begin{array}{c}\text { Antipsychotic } \\
\text { medication }\end{array}$ & $\begin{array}{l}\text { PANSS } \\
\text { SANS } \\
\text { CGI GAF } \\
\text { BACS } \\
\text { SAS }\end{array}$ & $\begin{array}{l}\text { Significant reduction of } \\
\text { positive symptoms, } \\
\text { better cognitive } \\
\text { performance and overall } \\
\text { functioning in CBD } \\
\text { group } \\
\text { No significant side-effects. } \\
\text { No correlations between } \\
\text { CBD plasma levels and } \\
\text { scale scores }\end{array}$ \\
\hline $\begin{array}{l}\text { Boggs et al. } \\
\quad(2018)\end{array}$ & $\begin{array}{l}\text { Double-blind, } \\
\text { randomised, } \\
\text { placebo-controlled, } \\
\text { parallel group trial }\end{array}$ & SKZ & $\begin{array}{l}18(12 / 6) \text { CBD } \\
\text { group }+18 \\
(13 / 5) \\
\text { Placebo } \\
\text { group }\end{array}$ & $18-65$ & $\begin{array}{r}600 \mathrm{mg} / \text { day } \\
\text { oral CBD }\end{array}$ & 6 weeks & $\begin{array}{c}\text { Antipsychotic } \\
\text { medication }\end{array}$ & $\begin{array}{l}\text { MCCB } \\
\text { PANSS }\end{array}$ & $\begin{array}{l}\text { No improvement in } \\
\text { cognitive scores and no } \\
\text { reduction of psychotic } \\
\text { symptoms }\end{array}$ \\
\hline
\end{tabular}




\begin{tabular}{|c|c|c|c|c|c|c|c|c|c|}
\hline $\begin{array}{l}\text { Crippa et al. } \\
\text { (2011) }\end{array}$ & $\begin{array}{l}\text { Double-blind, } \\
\text { randomised, } \\
\text { placebo-controlled, } \\
\text { repeated measures, } \\
\text { within-subjects } \\
\text { cross-over trial }\end{array}$ & $\begin{array}{l}\text { Treatment-naïve } \\
\text { generalised social } \\
\text { anxiety disorder }\end{array}$ & $10(10 / 0)$ & $20-33$ & $\begin{array}{l}400 \text { mg CBD } \\
\text { of gelatin } \\
\text { capsules } \\
\text { (with } \\
\text { powder } \\
\text { CBD } \\
\text { dissolved in } \\
\text { corn oil) }\end{array}$ & $\begin{array}{l}\text { One single } \\
\text { dose }\end{array}$ & I & $\begin{array}{l}\text { VAMS } \\
\text { SPECT }\end{array}$ & $\begin{array}{l}\text { Significant reduction of } \\
\text { subjective anxiety in } \\
\text { CBD group } \\
\text { Functional activity changes } \\
\text { in limbic and paralimbic } \\
\text { cerebral regions in CBD } \\
\text { group } \\
\text { No side effects }\end{array}$ \\
\hline $\begin{array}{l}\text { Bergamaschi } \\
\text { et al. (2011) }\end{array}$ & $\begin{array}{l}\text { Double-blind, } \\
\text { randomised, } \\
\text { placebo-controlled, } \\
\text { clinical trial }\end{array}$ & $\begin{array}{l}\text { Treatment-naïve } \\
\text { generalised social } \\
\text { anxiety disorder }\end{array}$ & $\begin{array}{l}12(6 / 6) \text { CBD } \\
\text { group } \\
12(6 / 6) \text { place } \\
\text { group } \\
12(6 / 6) \mathrm{HC}\end{array}$ & & $\begin{array}{l}600 \text { mg CBD } \\
\text { in gelatin } \\
\text { capsules } \\
\text { (with } \\
\text { powder } \\
\text { CBD } \\
\text { dissolved in } \\
\text { corn oil) }\end{array}$ & $\begin{array}{l}\text { One single } \\
\text { dose }\end{array}$ & I & $\begin{array}{l}\text { VAMS } \\
\text { SSPS } \\
\text { BSS }\end{array}$ & $\begin{array}{l}\text { Significant reduction of } \\
\text { anxiety symptoms, } \\
\text { cognitive impairment } \\
\text { and speech performance } \\
\text { discomfort in CBD group }\end{array}$ \\
\hline $\begin{array}{l}\text { Zuardi et al. } \\
\quad(2010)\end{array}$ & Case report & $\begin{array}{l}\text { Bipolar disorder type } \\
\text { I, manic episode } \\
\text { with psychotic } \\
\text { features }\end{array}$ & $2(0 / 2)$ & $\begin{array}{l}25 \\
17\end{array}$ & $\begin{array}{l}600 \mathrm{mg} \text { CBD } \\
\text { (up to } 1200 \\
\text { mg/day) }\end{array}$ & 25 days & $\begin{array}{l}\text { Olanzapine } \\
\text { during the first } \\
2 \text { weeks }\end{array}$ & $\begin{array}{l}\text { BPRS } \\
\text { YMRSUKU }\end{array}$ & $\begin{array}{l}\text { No significant symptoms } \\
\text { improvements with } \\
\text { CBD. } \\
\text { No side effects }\end{array}$ \\
\hline $\begin{array}{l}\text { Crippa et al. } \\
\text { (2013) }\end{array}$ & Case report & $\begin{array}{l}\text { Cannabis dependence } \\
\text { and cannabis } \\
\text { withdrawal } \\
\text { syndrome }\end{array}$ & $1(0 / 1)$ & 19 & $\begin{array}{l}300 \text { up to } 600 \\
\text { mg on in } \\
\text { gelatin } \\
\text { capsules } \\
\text { (with } \\
\text { powder } \\
\text { CBD } \\
\text { dissolved in } \\
\text { corn oil) }\end{array}$ & 10 days & I & $\begin{array}{l}\text { WDSM } \\
\text { WSC } \\
\text { BAI } \\
\text { BDI }\end{array}$ & $\begin{array}{l}\text { Reduction of withdrawal, } \\
\text { anxiety and dissociative } \\
\text { symptoms } \\
\text { No significant effect on } \\
\text { long-term cannabis } \\
\text { dependence }\end{array}$ \\
\hline $\begin{array}{l}\text { Shannon and } \\
\text { Opila- } \\
\text { Lehman } \\
\text { (2015) }\end{array}$ & Case report & $\begin{array}{l}\text { Cannabis } \\
\text { dependence, } \\
\text { bipolar disorder }\end{array}$ & $1(1 / 0)$ & 27 & $\begin{array}{l}18 \text { up to } 24 \\
\text { mg CBD oil }\end{array}$ & $\begin{array}{l}\text { Prolonged } \\
\text { over time }\end{array}$ & I & $\begin{array}{l}\text { PSQI } \\
\text { HAM-A }\end{array}$ & $\begin{array}{l}\text { CBD was effective in } \\
\text { quitting cannabis abuse, } \\
\text { in reducing anxiety } \\
\text { symptoms and } \\
\text { improving quality of life }\end{array}$ \\
\hline
\end{tabular}

Continued 


\begin{tabular}{|c|c|c|c|c|c|c|c|c|c|}
\hline Article & Study design & Diagnosis & Sample (M/F) & $\begin{array}{c}\text { Age } \\
\text { (years old) }\end{array}$ & $\begin{array}{l}\text { CBD dosage/ } \\
\text { formulation }\end{array}$ & CBD timing & Augmentation & $\begin{array}{c}\text { Scales, test } \\
\text { and } \\
\text { measurements }\end{array}$ & Main results \\
\hline $\begin{array}{l}\text { Morgan et al. } \\
\text { (2013) }\end{array}$ & $\begin{array}{l}\text { Double-blind, } \\
\text { randomised, } \\
\text { placebo-controlled } \\
\text { clinical trial }\end{array}$ & Tobacco use disorder & $\begin{array}{l}18(12 / 6) \text { CBD } \\
\text { group } \\
12(6 / 6) \\
\text { placebo } \\
\text { group }\end{array}$ & $18-35$ & $\begin{array}{l}\text { CBD }(400 \mu \mathrm{g} \\
\text { dose for } \\
\text { each } \\
\text { depress of } \\
\text { the solution } \\
\text { aerosol in } \\
\text { the inhaler }) \\
\text { via a } \\
\text { pressurised } \\
\text { metered } \\
\text { dose inhaler }\end{array}$ & 1 week & / & $\begin{array}{l}\text { STAI } \\
\text { BDI } \\
\text { BIS }\end{array}$ & $\begin{array}{l}\text { Significant reduction of } \\
\text { cigarettes smoked in } \\
\text { CBD group. No } \\
\text { significant effects on } \\
\text { craving. No side effects }\end{array}$ \\
\hline
\end{tabular}

BACS, Brief Assessment of Cognition in Schizophrenia; BAI, Beck Anxiety Inventory; BARS, Barnes Akathisia Rating Scale; BDI, Beck Depression Inventory; BIS, Behaviour Impulsivity Scale; BPRS, Brief Psychiatric Rating Scale; BSS, Bodily Symptoms Scale; CBD, cannabidiol; CGI, Global Clinical Impression Scale; EPS, Extrapyramidal Symptoms Rating Scale; FAAH, fatty acid amide hydrolase; FAB, Frontal Assessment Battery; GAF, Global Assessment of Functioning; Hamilton Anxiety Rating Scale; HC, healthy controls; IOPSI, Interactive Observation Scale for Psychiatric Inpatients; MCCB, Matrix Consensus Cognitive Battery; MMSE, Mini-Mental Status Examination; MWSC, Marijuana Withdrawal Symptom Checklist; NIA, no information available; PANSS-N, Negative Subscale of Positive and Negative Syndrome Scale; PPQ, Parkinson Psychosis Questionnaire; PSQI, Pittsburgh Sleep Quality Index; SANS, Scale for Assessment of Negative Symptoms; SAS, Social Anxiety Scale; SAS, Simpson-Angus Scale for Parkinson; SCWT, Stroop Color-Word Test; SKZ, schizophrenia; SPECT, single-photon emission computer tomography; SPSS, Self-Statements during Public Speaking Scale; STAI, Spielberger Trait Anxiety Inventory; UKU, UKU Side Effect Rating Scale; UPDRS, Unified Parkinson's Disease Rating Scale; VAMS, Visual Analogue Mood Scale; WDS, Withdrawal Discomfort Score; YMRS, Young Mania Rating Scale. 
research group, in patients diagnosed with generalised social anxiety disorder (SAD) (Bergamaschi et al. 2011; Crippa et al. 2011). Interestingly, the authors showed that a single dose of CBD not only significantly decreased subjective anxiety symptoms (Crippa et al. 2011), but also reduced cognitive impairment, speech performance discomfort and alert in anticipatory speech during a Simulation Public Speaking Test (Bergamaschi et al. 2011), in comparison to the placebo group.

In this regard, the anxiolytic effect exerted by CBD has been mainly related to its agonist activity towards serotonin type 1A (5HT1A) receptors (Soares \& Campos, 2017) in specific cerebral areas, including the dorsal periaqueductal grey, the bed nucleus of the stria terminalis and the medial prefrontal cortex (Campos et al. 2012). Specifically, even if the exact agonist mechanism is still unclear, some authors proposed that $\mathrm{CBD}$ may activate $5 \mathrm{HT} 1 \mathrm{~A}$ receptors by increasing guanosine-5'-triphosphate binding to $G_{i}$ protein and by reducing cyclic adenosine monophosphate concentration, similarly to the serotonin neurotransmitter (Russo et al. 2005). Moreover, the acute anxiolytic effect of CBD has also been related to its capacity to modify cerebral blood flow in brain sites typically involved in anxiety, such as amygdala, hippocampus, hypothalamus and cingulate cortex (Soares \& Campos, 2017). In this perspective, Crippa et al. (Crippa et al. 2011) performed a cerebral single-photon emission computed tomography scan in ten patients with SAD before and after acute CBD or placebo administration. Interestingly, the authors showed that while a reduced regional cerebral blood flow in left parahippocampal gyrus, hippocampus and inferior temporal gyrus was detected among the patients taking CBD, an increased radiotracer uptake was found in the right posterior cingulate gyrus in the same group.

In conclusion, these findings suggest that, in patients with SAD, CBD may exert an acute anxiolytic effect when administered in a single high dose. Remarkably, this effect may be mainly related to the capacity of CBD to suddenly modify cerebral blood flow in limbic and paralimbic areas (Crippa et al. 2011) and to agonise 5HT1A receptors (Bergamaschi et al. 2011).

\section{CBD and substance abuse disorder}

The pharmacological effects of CBD have also been tested in the treatment of substance abuse disorder by three studies. The case report carried out by Crippa et al. (Crippa et al. 2013) found that a 10 days oral administration of CBD may acutely reduce withdrawal, anxiety and dissociative symptoms in a patient with cannabis dependence who previously failed to quit cannabis consumption due to serious abstinence symptoms. However, the authors showed that 10 days treatment with CBD was not effective to interrupt long-term relapses of cannabis abuse (Crippa et al. 2013). In contrast, in a subsequent case report, Shannon and Opila-Lehman (Shannon \& OpilaLehman, 2015) reported that a prolonged administration of CBD to one BD patient with cannabis dependence not only reduced anxiety symptoms and ameliorate overall quality of life, but also prevented the patient from resuming cannabis consumption. Finally, a potential role of CBD in the treatment of tobacco use disorder has been suggested by the only one double-blind randomised controlled clinical trial performed by Morgan et al., who showed that the CBD group significantly decreased the number of cigarettes smoked without, though, exhibiting any specific beneficial effects on craving symptoms, compared with the placebo group (Morgan et al. 2013).

Overall these results might be explained considering that long-term cannabis consumption has been linked to a progressive desensitisation and downregulation of CB1R, which, in turn, may cause the onset of withdrawal symptoms when the substance is missing (Bonnet \& Preuss, 2017). Therefore, the capacity of CBD to reduce substance-induced withdrawal symptoms has been attributed to its ability to acutely antagonise CB1R and to chronically enhance the physiological endocannabinoid neurotransmission (Prud'Homme et al. 2015). With regards to tobacco addiction, the inhibition of acid amide hydrolase induced by $\mathrm{CBD}$ has been hypothesised to reduce the reinforcing effects of nicotine (Morgan et al. 2013). Additionally, the agonist activity of CBD towards 5HT1A receptors may also contribute to the anti-craving effect of $\mathrm{CBD}$ and to reduce the relapses of substance abuse by regulating drug reward system, anxiety symptoms and stress management (Prud'Homme et al. 2015). Finally, CBD may regulate the glutamatergic signalling through modulation of serotoninergic and endocannabinoid systems and this mechanism may also have a role in the treatment of addictive behaviours (Rodríguez-Muñoz et al. 2016), since a dysregulation of glutamatergic transmission has been widely related to both drug-seeking behaviours and abuse relapses (Prud'Homme et al. 2015).

These evidences suggest that acute administration of CBD may reduce withdrawal symptoms of cannabis dependence (Crippa et al. 2013), but the treatment needs to be prolonged over time in order to help quitting cannabis (Shannon \& Opila-Lehman, 2015) or tobacco use (Morgan et al. 2013). The efficacy of CBD in the treatment of addictive disorders has been mostly hypothetically linked to the modulation of endocannabinoid, serotoninergic and glutamatergic systems. 


\section{CBD and cognitive impairment in psychiatric patients}

As regards to neuropsychological functioning, three studies have considered the pro-cognitive effects of CBD in psychotic patients (Hallak et al. 2010; Boggs et al. 2018; McGuire et al. 2018). A single oral dose (Hallak et al. 2010) or a 6-week oral administration (Boggs et al. 2018) of CBD were not more effective than placebo in ameliorating cognitive performances among outpatients with SKZ. In contrast, McGuire et al. (McGuire et al. 2018) detected a trend of higher enhancement, although not statistically significant, in cognitive performance and overall functioning in patients with SKZ treated with oral CBD for 6 weeks in adjunction to their ongoing antipsychotic medications.

As a whole, these findings are not surprising, especially because preclinical studies attributed the potential role of $\mathrm{CBD}$ in the treatment of cognitive impairment to its capacity to reduce both inflammatory state and oxidative stress as well to promote neurogenesis by increasing brain-derived neurotrophic factor levels (Osborne et al. 2017). Finally, the activity of CBD towards 5HT1A and adenosine $\mathrm{A} 2 \mathrm{~A}$ receptors may also contribute to improve cognitive performances (Osborne et al. 2017).

Therefore, it may be speculated that CBD procognitive effects may need longer time of administration in order to detect significant cognitive enhancement, since acute or long-term CBD administration within 6 weeks seemed to not significantly improve cognitive functioning in SKZ patients (Hallak et al. 2010; Boggs et al. 2018; McGuire et al. 2018).

\section{Conclusions}

In conclusion, the so far investigated mechanisms of action of CBD may likely explain the preliminary evidences of efficacy in the treatment of psychiatric disorders, especially in psychotic, anxiety and substanceinduced disorders. However, the findings presented in this literature overview must be considered in light of some limitations. First, there are still few randomised placebo-controlled clinical trials with small sample size. Second, CBD was administered in inconsistent dosage, formulation and timing of administration. Third, some studies tested CBD efficacy in adjunction to standard medications (Zuardi et al. 1995, 2009, 2010; Leweke et al. 2012; Boggs et al. 2018; McGuire et al. 2018), which may have therefore conditioned the results. Fourth, major considerations must be given to the lack of assessment of biological measures among the abovementioned studies, since only three studies evaluated biological measures, such as endocannabinoid (Leweke et al. 2012) or CBD plasma levels (McGuire et al. 2018) and cerebral blood flow changes (Crippa et al. 2011).
Nonetheless, all together, such preliminary evidences suggest that CBD may have an effective therapeutic role in the treatment of psychiatric disorders. However, further and larger randomised placebo-controlled clinical trials studies should be performed considering not only the clinical outcomes of CBD administration, but also its effect on biological parameters such as neurotransmitter signalling, pharmacokinetics, structural and functional cerebral modifications. This approach may help to clarify the wide spectrum of action of this new molecule in psychiatric disorders.

\section{Acknowledgements}

This study was partially supported by a grant from the AIFA (Proposal 2016-02364852).

\section{References}

Bergamaschi MM, Queiroz RHC, Chagas MHN, De Oliveira DCG, De Martinis BS, Kapczinski F, Quevedo J, Roesler R, Schröder N, Nardi AE, Martín-Santos R, Hallak JEC, Zuardi AW, Crippa JAS (2011). Cannabidiol reduces the anxiety induced by simulated public speaking in treatment-nave social phobia patients.

Neuropsychopharmacology 36, 1219.

Boggs DL, Surti T, Gupta A, Gupta S, Niciu M, Pittman B (2018). The effects of cannabidiol (CBD) on cognition and symptoms in outpatients with chronic schizophrenia a randomized placebo controlled trial. Schizophrenia Bulletin 44, 46-53.

Bonnet U, Preuss U (2017). The cannabis withdrawal syndrome: current insights. Substance Abuse and Rehabilitation 8, 9-37.

Campos AC, Moreira FA, Gomes FV, Del Bel EA, Guimaraes FS (2012). Multiple mechanisms involved in the large-spectrum therapeutic potential of cannabidiol in psychiatric disorders. Philosophical Transactions of the Royal Society B: Biological Sciences 367, 3364-3378.

Crippa JAS, Nogueira Derenusson G, Borduqui Ferrari T, Wichert-Ana L, Duran FLS, Martin-Santos R, Vinícius Simões M, Bhattacharyya S, Fusar-Poli P, Atakan Z, Santos Filho A, Freitas-Ferrari MC, McGuire PK, Zuardi AW, Busatto GF, Hallak JEC (2011). Neural basis of anxiolytic effects of cannabidiol (CBD) in generalized social anxiety disorder: a preliminary report. Journal of Psychopharmacology 25, 121-130.

Crippa JAS, Hallak JEC, Machado-De-Sousa JP, Queiroz RHC, Bergamaschi M, Chagas MHN, Zuardi AW (2013). Cannabidiol for the treatment of cannabis withdrawal syndrome: a case report. Journal of Clinical Pharmacy and Therapeutics 38, 162-164.

de Mello Schier AR, de Oliveira Ribeiro NP, Coutinho DS, Machado S, Arias-Carrión O, Crippa JA, Zuardi AW, Nardi AE, Silva AC (2014). Antidepressant-like and anxiolytic-like effects of cannabidiol: a chemical compound 
of Cannabis sativa. CNS \& Neurological Disorders Drug Targets 13, 953-960.

Di Marzo V, Petrosino S (2007). Endocannabinoids and the regulation of their levels in health and disease. Current Opinion in Lipidology 18, 129-140.

Fasinu PS, Phillips S, ElSohly MA, Walker LA (2016). Current status and prospects for cannabidiol preparations as new therapeutic agents. Pharmacotherapy 36, 781-796.

Gururajan A, Malone DT (2016). Does cannabidiol have a role in the treatment of schizophrenia? Schizophrenia Research 176, 281-290.

Hahn B (2018). The potential of cannabidiol treatment for cannabis users with recent-onset psychosis. Schizophrenia Bulletin 44, 46-53.

Hallak JEC, Machado-de-Sousa JP, Crippa JAS, Sanches RF, Trzesniak C, Chaves C, Bernardo SA, Regalo SC, Zuardi AW (2010). Performance of schizophrenic patients in the Stroop Color Word Test and electrodermal responsiveness after acute administration of cannabidiol (CBD). Revista Brasileira de Psiquiatria 32, 56-61.

Laprairie RB, Bagher AM, Kelly MEM, Denovan-Wright EM (2015). Cannabidiol is a negative allosteric modulator of the cannabinoid CB1 receptor. British Journal of Pharmacology 172, 4790-4805.

Lee JLC, Bertoglio LJ, Guimarães FS, Stevenson CW (2017). Cannabidiol regulation of emotion and emotional memory processing: relevance for treating anxiety-related and substance abuse disorders. British Journal of Pharmacology 174, 3242-3256.

Leweke M (2013). The endocannabinoid system in schizophrenia-a mechanistically new approach to its pathophysiology and treatment. Schizophrenia Bulletin 39, S341.

Leweke FM, Piomelli D, Pahlisch F, Muhl D, Gerth CW, Hoyer C, Klosterkötter J, Hellmich M, Koethe D (2012). Cannabidiol enhances anandamide signaling and alleviates psychotic symptoms of schizophrenia. Translational Psychiatry 2, e94.

Lötsch J, Weyer-Menkhoff I, Tegeder I (2018). Current evidence of cannabinoid-based analgesia obtained in preclinical and human experimental settings. European Journal of Pain (United Kingdom) 22, 471-484.

McGuire P, Robson P, Cubala WJ, Vasile D, Morrison PD, Barron R, Taylor A, Wright S (2018). Cannabidiol (CBD) as an adjunctive therapy in schizophrenia: a multicenter randomized controlled trial. The American Journal of Psychiatry 175, 225-231.

Morgan CJA, Das RK, Joye A, Curran HV, Kamboj SK (2013). Cannabidiol reduces cigarette consumption in tobacco smokers: preliminary findings. Addictive Behaviors 38, 2433-2436.

Osborne AL, Solowij N, Weston-Green K (2017). A systematic review of the effect of cannabidiol on cognitive function: relevance to schizophrenia. Neuroscience and Biobehavioral Reviews 72, 310-324.

Parker LA, Rock EM, Limebeer CL (2011). Correspondence regulation of nausea and vomiting by cannabinoids. British Journal of Pharmacology 163, 1411-1422.

Perucca E (2017). Cannabinoids in the treatment of epilepsy: hard evidence at last? Journal of Epilepsy Research 7, 61-76.

Pisanti S, Malfitano AM, Ciaglia E, Lamberti A, Ranieri R, Cuomo G, Abate M, Faggiana G, Proto MC, Fiore D, Laezza C, Bifulco M (2017). Cannabidiol: state of the art and new challenges for therapeutic applications. Pharmacology and Therapeutics 175, 133-150.

Prud'Homme M, Cata R, Jutras-Aswad D (2015). Cannabidiol as an intervention for addictive behaviors: a systematic review of the evidence. Substance Abuse: Research and Treatment 9, 33-38.

Rodríguez-Muñoz M, Sánchez-Blázquez $P$, Merlos $M$, Garzón-Niño J (2016). Endocannabinoid control of glutamate NMDA receptors: the therapeutic potential and consequences of dysfunction. Oncotarget 7, 55840-55862.

Russo EB, Burnett A, Hall B, Parker KK (2005). Agonistic properties of cannabidiol at 5-HT1a receptors. Neurochemical Research 30, 1037-1043.

Seeman P (2016). Cannabidiol is a partial agonist at dopamine D2High receptors, predicting its antipsychotic clinical dose. Translational Psychiatry 6, e920.

Shannon S, Opila-Lehman J (2015). Cannabidiol oil for decreasing addictive use of marijuana: a case report. Integrative Medicine (Encinitas) 14, 31.

Soares VP, Campos AC (2017). Evidences for the antipanic actions of cannabidiol. Current Neuropharmacology 15, 291-299.

Watt G, Karl T (2017). In vivo evidence for therapeutic properties of cannabidiol (CBD) for Alzheimer's disease. Frontiers in Pharmacology 8, 20.

Zuardi AW, Morais SL, Guimaraes FS, Mechoulam R (1995). Antipsychotic effect of cannabidiol [3]. Journal of Clinical Psychiatry 56, 485-486.

Zuardi AW, Hallak JEC, Dursun SM, Morais SL, Sanches RF, Musty RE, Crippa JAS (2006). Cannabidiol monotherapy for treatment-resistant schizophrenia. Journal of Psychopharmacology 20, 683-686.

Zuardi AW, Crippa JAS, Hallak JEC, Pinto JP, Chagas MHN, Rodrigues GGR, Dursun SM, Tumas V (2009). Cannabidiol for the treatment of psychosis in Parkinsons disease. Journal of Psychopharmacology 23, 979-983.

Zuardi AW, Crippa JAS, Dursun SM, Morais SL, Vilela JAA, Sanches RF, Hallak JEC (2010). Cannabidiol was ineffective for manic episode of bipolar affective disorder. Journal of Psychopharmacology 24, 135-137. 